\title{
Sequence of apoptosis and inflammatory necrosis within the formative ovulatory site of sheep follicles
}

\author{
W. J. Murdoch, C. Wilken and D. A. Young \\ Department of Animal Science, University of Wyoming, Laramie, WY 82071, USA
}

\begin{abstract}
The aim of this study was to define the temporal and spatial patterns of apoptosis, necrosis and inflammation within preovulatory ovine follicles. A gonadotrophin surge was induced in pro-oestrous ewes by $\mathrm{GnRH}$, and isolated follicles were hemisected into apical and basal segments at 0, 10, 18 and $22 \mathrm{~h}$ (the time of ovulatory stigma development) after GnRH. Ovarian surface epithelial and granulosa cells were isolated and assessed by fluorescence microscopy for membrane phosphatidylserine translocation-annexin V (early-stage apoptosis), oligonucleosomal DNA nick endlabelling (advanced apoptosis), and nuclear propidium iodide incorporation (necrotic membrane disruption). Thecal shells were analysed for interstitial blood cells. Preovulatory follicles were also hemisected and subjected to electrophoretic DNA degradation analysis. Annexin $\mathrm{V}$ binding and in situ DNA fragmentation among ovarian surface epithelial and granulosa cells along the follicular apex were high 18 and $22 \mathrm{~h}$ after GnRH. Propidium iodide staining of apical ovarian surface and granulosa cells was apparent at $22 \mathrm{~h}$. There was a coincident increase within the apical theca as the time of ovulation approached in extravasated leucocytes (18 and $22 \mathrm{~h}$ ) and erythrocytes (22 h). Apoptotic DNA laddering and necrotic DNA smears within the follicular apex were evident on agarose gels at 18 and $22 \mathrm{~h}$, respectively. In contrast, ovarian surface epithelium not associated with the ovulation site and the basal follicular wall were largely unafflicted. It is suggested that both modalities of cellular death, apoptosis and necrosis (with acute inflammation and vascular injury), contribute progressively to follicular stigma formation and ovarian rupture.
\end{abstract}

\section{Introduction}

Two fundamental mechanisms of cellular death, apoptosis and necrosis, have been delineated. Apoptosis is a genetically programmed process of organ morphogenesis and remodelling that involves individual cells. During earlystage apoptosis phosphatidylserine is transposed from the inner leaflet to the outer surface of the plasma membrane. Internucleosomal DNA cleavage (laddering) and nuclear condensation ensue. Afflicted cells shrink and fragment into apoptotic bodies; they can become undetectable (by sloughing and phagocytic resorption) within a few hours. Necrosis is a passive phenomenon of contiguous cells affected by ischaemia (oncosis) or noxious trauma. The plasma membrane of necrotic cells is permeable to macromolecules and DNA is degraded in a non-selective manner (creating a smear on agarose gels). Extravasation of blood cells and vascular damage are often associative features of necrosis. In many cases of tissue insult, an initial apoptotic wave is succeeded by necrosis and inflammation (Columbano, 1995; Haanen and Vermes, 1995; Majno and Joris, 1995; Allen et al., 1997; Cummings et al., 1997).

Received 29 December 1998.
Ovulatory ovarian rupture is characterized by physiological and inflammatory tissue destruction. Ovarian surface, endothelial, and granulosa cells within the formative site of ovulation (stigma) exhibit biochemical and morphological signs of apoptosis (Murdoch, 1995a,b). That the mechanism of mammalian ovulation resembles an acute inflammatory reaction has been recognized for many years (Espey, 1980). The purpose of this study was to determine the time-course of apoptosis, necrosis, and inflammation within the apical and basal compartments of the preovulatory ovine follicular wall.

\section{Materials and Methods}

Experiments were approved by the University of Wyoming Animal Care and Use Committee. Reagents were purchased from Sigma Chemical Co. (St Louis, MO) unless stated otherwise.

Mature western range ewes were penned daily with vasectomized rams and observed for oestrous behaviour. The first day of oestrus was considered day 0 . On day 14 of the oestrous cycle, animals were injected i.m. with $10 \mathrm{mg}$ prostaglandin (PG) $\mathrm{F}_{2 \alpha}$ tromethamine (Lutalyse; Upjohn, 
Kalamazoo, MI) to synchronize luteal regression. A synthetic agonist of GnRH (des Gly ${ }^{10}-\mathrm{Ala}^{6}$ ethylamide; $5 \mu \mathrm{g}$ ) was administered i.m. $36 \mathrm{~h}$ later to elicit a preovulatory surge of gonadotrophins. A dominant follicle ( $\geq 6 \mathrm{~mm}$ in diameter) will ovulate approximately $24 \mathrm{~h}$ after $\mathrm{GnRH}$ administration (Roberts et al., 1985).

Animals were killed and ovaries were obtained (i.v. Beuthanasia, Schering-Plough Animal Health, Kenilworth, $\mathrm{NJ}$ ) at $0,10,18$ and $22 \mathrm{~h}$ after GnRH (pregonadotrophin stimulation, early preovulatory period, late preovulatory period, and ovulation imminent, respectively); six ewes were assigned at random to each group (normal ovulation rate = $1-2)$. The largest follicle $(6-8 \mathrm{~mm})$ was isolated and hemisected using a single-edged razor blade into apical (ovarian surface epithelium, tunica albuginea, theca and granulosa) and basal (theca and granulosa) components. Ovarian surface epithelial cells along the apical hemisphere and at a peripheral (non-follicular) site were removed using a teflon scraper designed to dislodge adherent cells from culture flasks (Becton Dickinson Co., Lincoln Park, NJ). Cells were rinsed from the edge of the scraper using $0.6 \mathrm{ml}$ PBS. Granulosa cells were isolated similarly from the apical and basal (that is, exposed antral) surfaces of follicles by gentle scraping. Cells were suspended by gentle agitation and aliquoted into three portions (approximately 250 per $0.2 \mathrm{ml}$ ) to be analysed for membrane phospholipid asymmetry (early apoptosis), oligonucleosomal DNA nick end-labelling (progressive apoptosis), or nuclear propidium iodide incorporation (necrotic membrane disruption). Thecal shells for quantitation of extravascular blood cells (haemorrhage, leucocytic inflammation) were fixed by immersion in Histochoice (Amresco, Solon, $\mathrm{OH}$ ). A second preovulatory follicle $(6-7 \mathrm{~mm})$ was collected from each of four animals per group, hemisected and subjected to electrophoretic DNA analysis.

An ApoAlert ${ }^{\mathrm{TM}}$ Annexin V-Fluorescein Isothiocyanate (FITC) Kit (Clontech, Palo Alto, CA) was used to detect externalization of phosphatidylserine on unfixed cells according to the instructions of the manufacturer. Annexin V is an anticoagulant protein that binds preferentially the negatively charged phosphatidylserine in the presence of calcium (Martin et al., 1995).

An Oncor (Gaithersburg, MD) ApopTag TM S7111 in situ kit was used to monitor linker DNA cleavage in permeabilized cells as described in detail by the manufacturer; this technique detects apoptosis with a greater than tenfold higher sensitivity than it does necrosis (Gorczyca et al. 1993). Briefly, exposed 3 '-OH ends of DNA fragments were labelled with digoxigenin-11-d uridine triphosphate by terminal deoxynucleotidyl transferase $(\mathrm{TdT})$ catalysis. Incorporated nucleotide heteropolymers were localized with antidigoxigenin Fab-FITC.

Propidium iodide is a fluorescent marker that binds double-stranded nucleic acids of permeant (non-viable) cells (Sasaki et al., 1987). Cells were mixed with propium iodide at a final concentration of $50 \mathrm{mg} \mathrm{PBS} \mathrm{ml}^{-1}$ ( $\mathrm{pH} \mathrm{7.4)}$ for $10 \mathrm{~min}$.

Negative controls were performed in the absence of annexin V-FITC, TdT, or propium iodide. Cells were viewed with an Olympus $\mathrm{BH}-2$ microscope equipped with a reflected light fluorescence attachment (Tokyo) and a Pixera digital (1.2 million pixel) camera interface (Los Gatos, CA). Images of individual cells (30 per ovarian surface and granulosa sample site; $\times 400$ ) were captured and categorized (Optimas, Bothell, WA) as stained (luminance intensity $>2 \times$ background) or non-reactive. Data are expressed as a percentage of positively stained cells as a function of the total number of epithelial cells assessed.

Thecal tissues were washed in PBS, dehydrated in a graded series of ethanol, cleared in xylene, infiltrated with paraffin wax, sectioned at $5 \mu \mathrm{m}$ thickness, and stained in $0.5 \%(\mathrm{w} / \mathrm{v})$ azure blue (Cavender and Murdoch, 1988). Interstitial erythrocytes and leucocytes were counted within four random cross-sections $(\times 1000)$ of each specimen; subsample data were averaged for each animal.

Cellular data were evaluated by analysis of variance and protected least significant difference. Percentage values were transformed (arcsin) for statistical evaluation. Contrasts were considered significant at $P<0.05$.

Follicular DNA was isolated (digestion buffer: $100 \mathrm{mmol}$ $\mathrm{NaCl} \mathrm{l}^{-1}, 10 \mathrm{mmol}^{\text {Tris- }} \mathrm{HCl} \mathrm{l}{ }^{-1}, 25 \mathrm{mmol}_{\text {EDTA l}}{ }^{-1}, 5 \%(\mathrm{w} / \mathrm{v})$ SDS with proteinase $\mathrm{K}$, pH 8.0, $1 \mathrm{mg}$ per $10 \mathrm{ml}, 16 \mathrm{~h}, 55^{\circ} \mathrm{C}$; $3 \times$ extraction with $10 \%$ saturated phenol-chloroform-isoamyl alcohol 24:24:1; ethanol precipitation) using a Wizard Purification Kit (Promega, Madison, WI). Degradation of DNA was assessed by agarose gel electrophoresis $(1.8 \% ; 2 \mu \mathrm{g}$ per well, $3 \mathrm{~h}, 75 \mathrm{~V}, 1 \mathrm{mg}$ ethidium bromide stain $\mathrm{ml}^{-1}$ ) (Compton, 1992). Apical and basal hemispheres of one animal at every time of tissue collection were represented on each gel processed. The DNA was visualized under UV light. Laddering (positive control) was detected using the corpora lutea of ewes treated with prostaglandin $\mathrm{F}_{2 \alpha}$.

\section{Results}

A translucent apical stigma indicative of impending rupture was present on all follicles obtained at $22 \mathrm{~h}$ after injection of GnRH.

There were increases $(P<0.001)$ in annexin $V$ binding to ovarian surface epithelial and granulosa cells along the follicular apex at 18 and $22 \mathrm{~h}$ after administration of GnRH. Annexin $\mathrm{V}$ reactivities of ovarian surface cells that were not conjoined to the preovulatory follicle were negligible and not affected by time of collection. Moreover, basal granulosa cells were not generally stained with annexin-FITC; although there was a slight increase $(P<0.1)$ near the time of ovulation at $22 \mathrm{~h}$ (Fig. 1a).

Detection of fragmented DNA in situ within follicleassociated ovarian epithelia $(P<0.01)$ and apical granulosa $(P<0.05)$ increased at 18 and $22 \mathrm{~h}$ after $\mathrm{GnRH}$ injection. Nuclear evidence of apoptotic DNA degradation in peripheral ovarian surface and basal granulosa cells was low throughout the preovulatory period (Fig. 1b).

Internalization of propium iodide was apparent at $22 \mathrm{~h}$ after GnRH in follicle-associated ovarian surface $(P<0.001)$ and apical granulosa $(P<0.01)$ cells. Occurrences of necrotic death among cells distant from the presumptive site of ovulation were insignificant (Fig. 1c).

There was a successive increase in the number of extravascular leucocytes within the apical theca at 18 

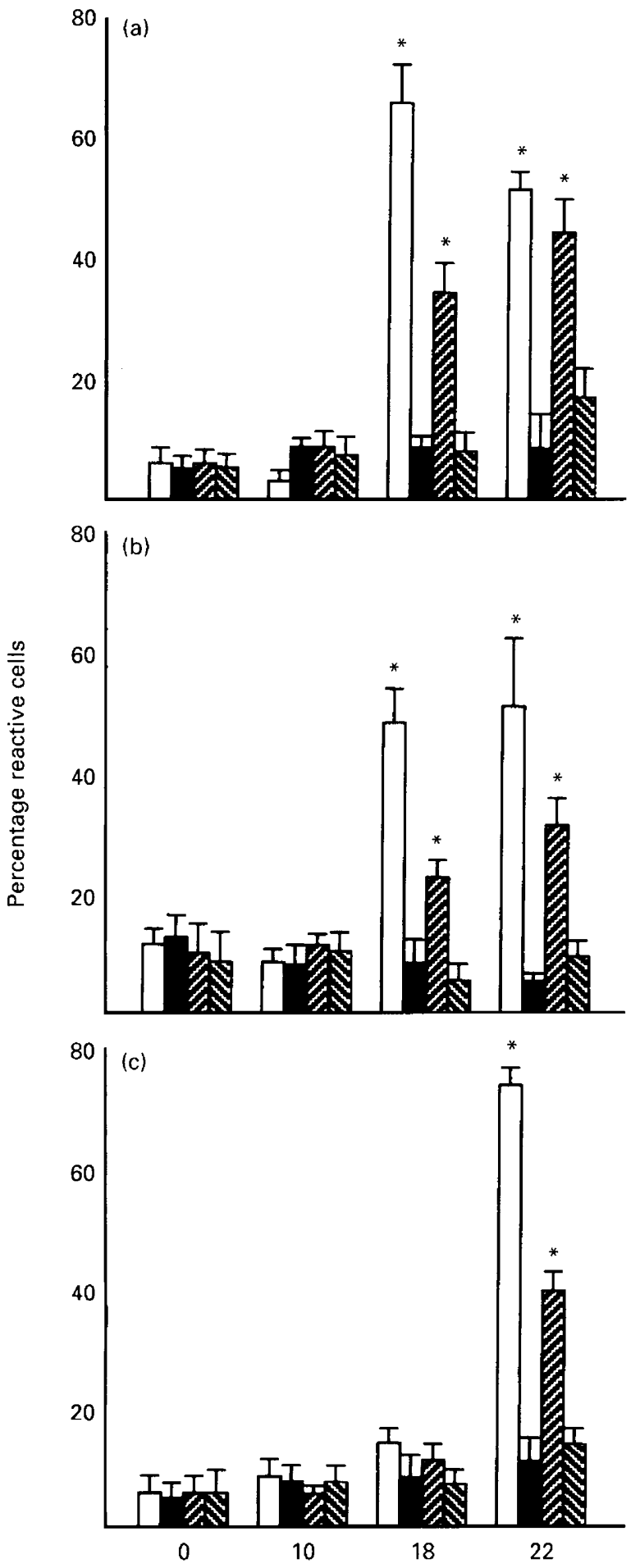

Time (h) after $\mathrm{GnRH}$ injection

Fig. 1. Preovulatory (a) annexin V, (b) DNA fragmentation, and (c) propium iodide staining of $(\square)$ follicle-associated and $(\boldsymbol{\square})$ peripheral ovarian surface epithelial and $(\boldsymbol{A})$ apical and $(\mathbf{N})$ basal granulosa cells of ewes. Means + SEM per time point are plotted. ${ }^{*}$ Significant increases from $0 \mathrm{~h}(P<0.05)$.

$(P<0.05)$ and $22 \mathrm{~h}(P<0.01)$ after injection of $\mathrm{GnRH}$. Extravasated erythrocytes were conspicuous $(P<0.001)$ within thecal apices at $22 \mathrm{~h}$. Blood cell influx into theca obtained from the basal region of preovulatory follicles did
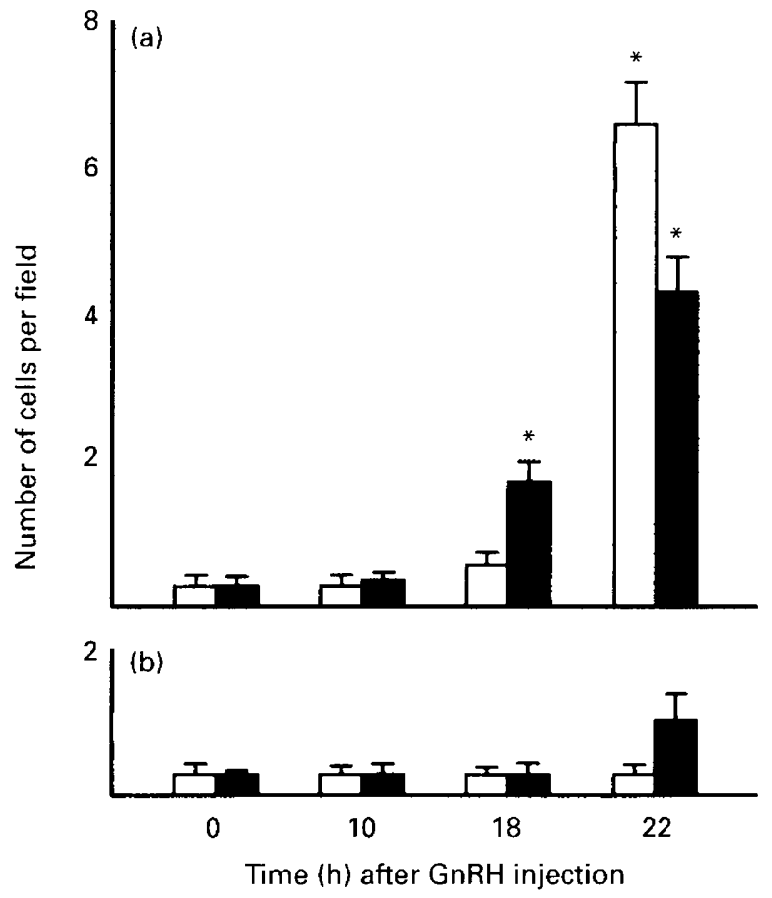

Fig. 2. Preovulatory thecal alterations in extravascular (a) apical and (b) basal ( $\square$ ) erythrocytes and ( per time point are plotted. *Significant increases from $0 \mathrm{~h}(P<0.05)$.

not usually occur; there was a tendency $(P<0.1)$ for the appearance of more interstitial leucocytes at $22 \mathrm{~h}$ after $\mathrm{GnRH}$ injection (Figs 2 and 3).

On agarose gels, there was no evidence of DNA degradation within follicular tissues obtained during the early preovulatory period ( $0-10 \mathrm{~h}$ after $\mathrm{GnRH}$ injection). Prototype patterns of apoptotic DNA laddering within the follicular apex were detected at $18 \mathrm{~h}$. Smears of DNA from apical follicular tissues were obvious at $22 \mathrm{~h}$. Concomitant cell death (inferred by cleaved DNA) was not discernible in basal follicular tissues (Fig. 4). Results were consistent among gels.

\section{Discussion}

Cell death can be either by suicide (apoptosis) or murder (necrosis). Ovulation is a hormone-programmed pathophysiological paradigm whereby both modes of cell destruction are invoked. This is the first report to our knowledge describing an acute progression of apoptosis and inflammatory necrosis within the developmental site of ovarian rupture.

Although idiosyncratic criteria have been used to discriminate apoptosis from necrosis, implying mechanistic differences between these two processes, a basic understanding of subservient molecular pathways of cell death are still too rudimentary to draw fixed boundaries. Indeed, many of the accepted effectors of apoptosis (for example, trophic factor withdrawal, oxidative stress, and protease activation) also cause necrosis. In addition, classical inducers of necrosis (for example, hypoxia) can produce apoptotic patterns of cell death. Furthermore, the relative strength of 


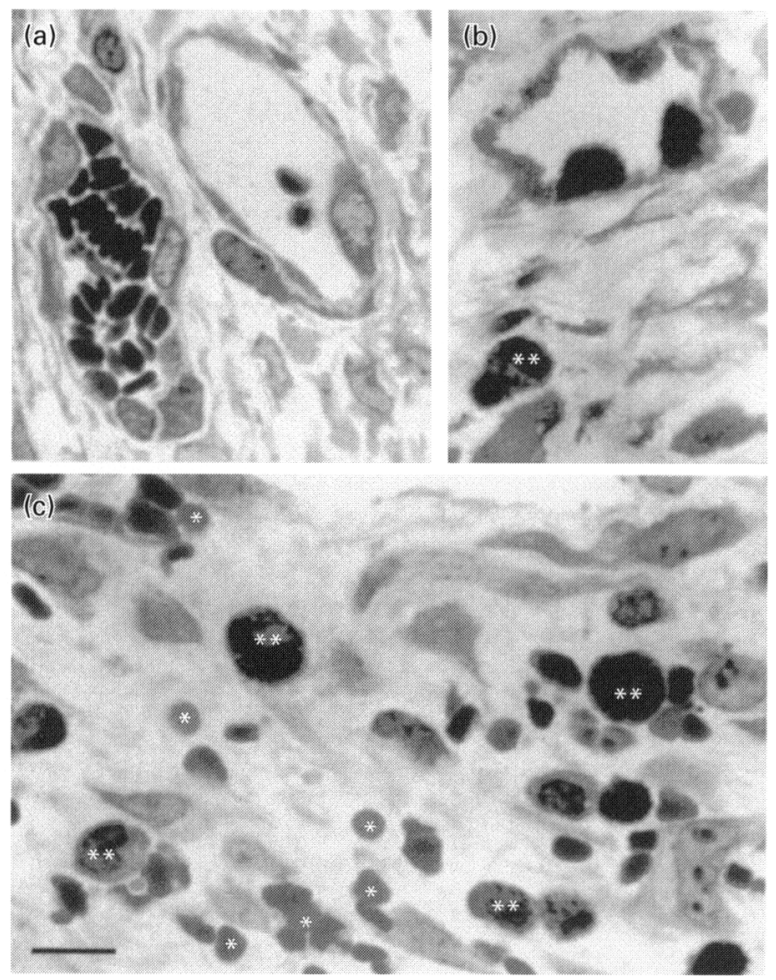

Fig. 3. Photomicrographs of (a) $10 \mathrm{~h}$ apical (intact blood vessels), (b) $22 \mathrm{~h}$ basal (**extravasated leucocyte), and (c) $22 \mathrm{~h}$ apical (note the lack of vascular integrity and denoted abundance of interstitial *red and ${ }^{* *}$ white blood cells) sheep thecal tissue sections. Scale bar represents $10 \mu \mathrm{m}$.

stimulus is sometimes important; tumour necrosis factor (TNF) $\alpha$ action is concentration-dependent (that is, at low concentrations, it triggers apoptosis and, at high concentrations, it causes vascular injury and haemorrhagic necrosis). It is apparent that mechanisms of cell death in vivo are not mutually exclusive (Columbano, 1995; Haanen and Vermes, 1995; Majno and Joris, 1995; Allen et al., 1997; Cummings et al., 1997).

In the specific context of ovulation, cell death does not occur until the later stages of the process, and then develops from a mild state of (apical) apoptosis to a cataclysmic condition of necrosis and diminution of vascular integrity. While some evidence of apoptosis and leucocytic infiltration were noted throughout the follicular wall, the focus of attack was within the ovarian surface-follicular dome. Discrete physico-chemical interactions within the formative ovulatory stigma are a prelude to cellular deletion, apical weakening, and ovarian rupture. Ovarian surface epithelial cells in close apposition to the preovulatory ovine follicle secrete urokinase-type plasminogen activator (in direct response to thecal-derived $\mathrm{LH}$ ), which upregulates plasmin production (within a limited diffusion radius) and cleavage of (apoptosis-inducing) TNF- $\alpha$ exodomain from thecal endothelium (Colgin and Murdoch, 1997; Murdoch et al., 1997; Murdoch, 1998). An eventual lack of blood flow into the ovulation papilla (Cavender and Murdoch, 1988), leading to oxygen deprivation and toxic metabolite

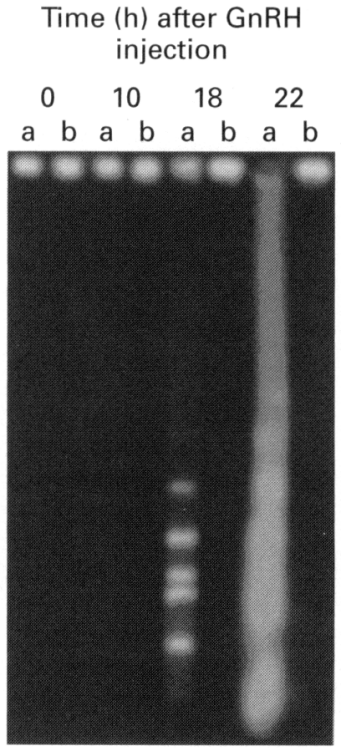

Fig. 4. Representative agarose gel of preovulatory ovine follicular DNA profiles. a: apex; $b$ : base. Apical internucleosomal cleavage and random degradation of DNA were evident at 18 and $22 \mathrm{~h}$, respectively.

accumulation, would potentiate cell death (Barr and Tomei, 1994). Leucocytes, which can release an array of cytotoxic mediators (Brännström and Norman, 1993; Pate, 1995), are attracted into the thecal interstitium by soluble fragments of collagen degradation (Murdoch and McCormick, 1992).

It appears that TNF- $\alpha$ is a terminal effector of ovulation. Incidences of apical ovarian cells with fragmented DNA and ovulation were inhibited by intrafollicular injection of TNF- $\alpha$ antibodies in ewes (Murdoch et al., 1997). Perfused rat ovaries released TNF- $\alpha$ into venous effluent during ovulation (Brännström et al., 1994), and the addition of TNF- $\alpha$ to perfusates increased LH-induced ovulation rates (Brännström et al., 1995). Preovulatory human and bovine follicles also secrete bioactive TNF- $\alpha$ (Zolti et al., 1990; Terranova, 1997; deMola et al., 1998).

Understanding of the signal transduction pathway that mediates the apoptotic effect of TNF- $\alpha$ is improving. Receptors of 55 (TNFR1) and 75 (TNFR2) kDa bind trimeric ligand through a homologous extracellular motif (Bazzoni and Beutler, 1995; Vandenabeele et al., 1995; Warzocha and Salles, 1998). TNFR1, which contains a cytoplasmic death domain (DD), initiates apoptosis (TNFR2 activates the transcriptional factor $N F \kappa \beta$ ). An aggregation of receptors orients the death domains in a conformation that recruits the adapter proteins, TRADD (TNFR-associated protein with a DD) and FADD (Fas-associated protein with a DD). The death effector region of FADD is able to recruit the zymogen forms of certain cysteine proteases (for example, FLICE/Macha1) that, upon activation, evoke a proteolytic cascade inciting DNA degradation and cell atrophy (Boldin et al., 1996; Muzio et al., 1996; Zhivotovsky et al., 1996; Alnemri, 1997). The capacity of TNF- $\alpha$ to disrupt endothelium leads to haemorrhagic necrosis (Larrick and Wright, 1990). Finally, tissue lesions involving apoptosis and 
necrosis are generally followed by a prompt regenerative response (Columbano, 1995): angiogenesis and nodus (for example, corpus luteum) formation.

It is concluded that apoptosis, acute inflammation and necrosis contribute progressively to follicular stigma formation and ovulatory ovarian rupture in ewes.

This research was supported by USDA-NRI grant 95-37203-2131.

\section{References}

Allen RT, Hunter WJ and Agrawal DK (1997) Morphological and biochemical characterization and analysis of apoptosis Journal of Pharmacological and Toxicological Methods 37 215-228

Alnemri ES (1997) Mammalian cell death proteases: a family of highly conserved asparate specific cysteine proteases Journal of Cellular Biochemistry $6433-42$

Barr PJ and Tomei LD (1994) Apoptosis and its role in human disease Biotechniques $12487-493$

Bazzoni F and Beutler B (1995) How do tumor necrosis factor receptors work? Journal of Inflammation 45 221-238

Boldin MP, Goncharov TM, Goltsev YV and Wallach D (1996) Involvement of $\mathrm{MACH}$, a novel MORT1/FADD-interacting protease, in Fas/APO-1 and TNF receptor-induced cell death Cell 85 803-815

Brännström M and Norman RJ (1993) Involvement of leukocytes and cytokines in the ovulatory process and corpus luteum function Human Reproduction 8 1762-1775

Brännström M, Norman RJ, Seamark RF and Robertson SA (1994) Rat ovary produces cytokines during ovulation Biology of Reproduction 50 88-94

Brännström M, Bonello N, Wang LJ and Norman RJ (1995) Effects of tumor necrosis factor $\alpha$ (TNF- $\alpha$ ) on ovulation in the rat ovary Reproduction Fertility Development 7 67-73

Cavender JL and Murdoch WJ (1988) Morphological studies of the microcirculatory system of periovulatory ovine follicles Biology of Reproduction 39 989-997

Colgin DC and Murdoch WJ (1997) Evidence for a role of the ovarian surface epithelium in the ovulatory mechanism of the sheep: secretion of urokinase-type plasminogen activator Animal Reproduction Science 47 197-204

Columbano A (1995) Cell death: current difficulties in discriminating apoptosis from necrosis in the context of pathological processes in vivo. Iournal of Cellular Biochemistry 58 181-190

Compton MM (1992) A biochemical hallmark of apoptosis: internucleosomal degradation of the genome Cancer and Metastasis Reviews 11 105-119

Cummings MC, Winterford CM and Walker NI (1997) Apoptosis American Journal of Surgical Pathology 21 88-101

deMola JRL, Goldfarb JM, Hecht BR, Baumgardner GP, Babbo CJ and Friedlander MA (1998) Gonadotropins induce the release of interleukin 1 $\beta$, interleukin- 6 and tumor necrosis factor $\alpha$ from the human preovulatory follicle American Journal of Reproductive Immunology 39 387-390
Espey LL (1980) Ovulation as an inflammatory reaction - a hypothesis Biology of Reproduction 22 73-106

Gorczyca W, Bigman K, Mittelman A, Ahmed T, Gong J, Melamed MR and Darzynkiewicz Z (1993) Induction of DNA strand breaks associated with apoptosis during treatment of leukemias Leukemia 7 659-670

Haanen C and Vermes I (1995) Apoptosis and inflammation Mediators of Inflammation 45-15

Larrick JW and Wright SC (1990) Cytotoxic mechanism of tumor necrosis factor $\alpha$ FASEB Journal 4 3215-3223

Majno G and Joris I (1995) Apoptosis, oncosis, and necrosis American Journal of Pathology 146 3-15

Martin SJ, Reutelingsperger CPM, McGahon AJ, Rader JA, van Schie RCAA, LaFace DM and Green DR (1995) Early redistribution of plasma membrane phosphatidylserine is a general feature of apoptosis regardless of the initiating stimulus: inhibition of $\mathrm{Bcl}-2$ and $\mathrm{Abl}$ Journal of Experimental Medicine 182 1545-1556

Murdoch WJ (1995a) Programmed cell death in preovulatory ovine follicles Biology of Reproduction 53 8-12

Murdoch WJ (1995b) Endothelial cell death in preovulatory ovine follicles: possible implication in the biomechanics of rupture Journal of Reproduction and Fertility 105 161-164

Murdoch WJ (1998) Regulation of collagenolysis and cell death by plasmin within the formative stigma of preovulatory ovine follicles fournal of Reproduction and Fertility 113 331-336

Murdoch WJ and McCormick RJ (1992) Sequence analysis of leukocyte chemoattractant peptides secreted by periovulatory ovine follicles Biochemical and Biophysical Research Communications 184 848-852

Murdoch WJ, Colgin DC and Ellis JA (1997) Role of tumor necrosis factor $\alpha$ in the ovulatory mechanism of ewes fournal of Animal Science 75 1601-1605

Muzio M, Chinnaiyan AM, Kischkel FC et al. (1996) FLICE, a novel FADDhomologous ICE/CED-3-like protease, is recruited to the CD95 (Fas/APO1) death-inducing signaling complex Cell $85817-827$

Pate JL (1995) Involvement of immune cells in regulation of ovarian function Journal of Reproduction and Fertility Supplement 49 365-377

Roberts AJ, Dunn TG and Murdoch WJ (1985) Induction of ovulation in proestrous ewes: identification of the ovulatory follicle and functional status of the corpus luteum Domestic Animal Endocrinology 2 207-210

Sasaki DT, Dumas SE and Engleman EG (1987) Discrimination of viable and non-viable cells using propidium iodide in two color immunofluorescence Cytometry $8413-420$

Terranova PF (1997) Potential roles of tumor necrosis factor $\alpha$ in follicular development, ovulation, and the life span of the corpus luteum Domestic Animal Endocrinology 14 1-15

Vandenabeele P, Declercq W, Beyaert R and Fiers W (1995) Two tumour necrosis factor receptors: structure and function Trends in Cell Biology 5392-399

Warzocha K and Salles G (1998) The tumor necrosis factor signaling complex: choosing a pathway toward cell death or cell proliferation Leukemia and Lymphoma $2981-92$

Zhivotovsky B, Burgess DH and Orrenius S (1996) Proteases and apoptosis Experentia 52 968-978

Zolti M, Meirom R, Shemesh M, Wollach D, Mashiach S, Shore $L$ and BenRafael Z (1990) Granulosa cells as a source and target organ for tumor necrosis factor $\alpha$ FEBS Letters 261 253-255 